\title{
Triple bottom line of the CSR concept and its reporting
}

\author{
Jaroslav Belas, Jr. ${ }^{1}$, and Katarina Zvarikova, ${ }^{2, *}$ \\ ${ }^{1}$ Alexander Dubcek University in Trencin, Faculty of Social and Economic Relations, Studentska 3, \\ 91150 Trencin, Slovakia \\ ${ }^{2}$ University of Zilina, Faculty of Operation and Economics of Transport and Communications, \\ Univerzitna 1, 01026 Zilina, Slovakia
}

\begin{abstract}
Research background: The global situation is alarming. Many scholars, politicians, non-profit organizations and journalists worldwide remind of these arising problems. Sustainability seems to be the only solution, and also many companies try to do their best to contribute to this issue.

Purpose of the article: CSR is considered a valuable tool in many fields profit, stakeholders, and environmental dimensions. All these dimensions are characterized by their specifics, but it is proven that CSR positively impacts all of them. But the frequent problem is that although the companies are aware of the stakeholders' importance, they are not able to report their activities or report them in an understanding way.

Methods: Methods of the literature review is used for the theoretical background to understand the importance of three dimensions of CSR. Method of analysis is used to analyze of GRI index.

Findings \& Value added: Literature review proves the importance of CSR towards all three dimensions. According to analysis of the DRI index, it is evident, that not only organizations from developed countries have reported, but also organizations from developing countries had become reporting. Following the result of our analysis, we can see that 1694 organizations from 80 countries try to come close to stakeholders and want to inform them about their activities.
\end{abstract}

Keywords: CSR; three dimensions of CSR; stakeholders; sustainability; environment; profit; the GRI index

JEL Classification: F18; F23; F64; M31

\footnotetext{
*Corresponding author: katarina.zvarikova@ffpedas.uniza.sk
} 


\section{INTRODUCTION}

According to many non-profit organizations, journalists, activists, and politicians worldwide, environmental issues have become an arousing problem in the last few years. All these groups mention the necessity to essentially solve this issue because it is claimed that we are the last generation who can reverse the alarming predictions of scientists. And it is proven that mainly young generations are environmentally oriented. But their attention is focused not only on environmental issues but also on sustainability (Musova et al., 2021). According to many studies, younger people are more willing to pay a higher price of the goods or services (compared to older generations) if they are produced or provided more responsibly. But on the other hand, it is necessary to point out the results of Boccia et al. study (2019), which claims that price remains one of the main factors to purchase decision making.

As the people had become more aware of their responsibility to the environment, they started to insist on more responsible production of the goods or services. This issue has become relevant for companies all over the world, and it is globally solved. If the company wants to be successful, it has to accept arousing pressure on the responsible enterprising and implement these requirements in its everyday life. The most significant pressure is focused on the industries which are considered the biggest pollution makers. But also, other companies are taking part in more responsible behaviour, and they try to implement responsible behaviour in their practices. All these practices are commonly named Corporate Social Responsibility (here and after CSR). Many studies prove that implementation of the CSR concept has a positive effect on companies worldwide.

These papers consist of four chapters. The first chapter is aimed at the theoretical background of CSR from the point of view of its three dimensions. The second chapter is devoted to CSR reports, whereby the next chapter is researched reporting according to continents. The last chapter is focused on the discussion and limitations of the research.

\subsection{Literature review}

It is necessary to highlight the fact that CSR is often interchangeable with the term sustainability in studies. CSR, considered as a strategic concept, is developed from the necessity to protect the environment, and behave more socially responsible, as the main problems of the current situation (Kurniatama et al., 2021). As it is mentioned by Nadanyiova (2021), the implementation of CSR has become a necessity for companies if they want to be competitive. Researches prove that companies with implemented CSR are better able to overcome their negative impact on the environment. Without any doubt, we can claim that CSR has become a vital issue not only in marketing but also in finance, strategic management, or social studies (Islam et al., 2021). However, CSR is not a trend of the present days. Many of the CSR practices were already implemented in the past (for example, Tomás Bat'a implemented many CSR practices in his entrepreneurship). But nowadays, the pressure from the public (also known as stakeholders) is rising and making the companies behave more environmentally and socially responsible. Haleem et al. (2021) distinguish different stakeholders with their diverse interests of pressure. They identify, for example, NGOs as the stakeholders with the focus on the social dimensions and other stakeholders identified as customers or governments with the aim on the environmental dimension of entrepreneurship. Apart from the type of stakeholders, many of the studies prove the positive relationships between the implementation of sustainability practices and the pressure from the stakeholders (Haleem et al., 2021, Nadanyiova, 2021).

There is no generally accepted definition of the CSR concept, but all definitions come from the prerequisite of voluntariness and the fact that activities are often beyond the condition required by the law (Bardos et al.; 2020, Nadanyova, 2021; Metzker et al., 2021). 
The CSR concept is developed in 3 dimensions, also known as $3 \mathrm{P}$ - people, planet, and profit, as well as sustainability which integrates three responsibilities - responsibility for social, environmental, and economic issues. However, as it is mentioned by Haleem et al. (2021) the environmental dimension is more researched by the studies than a social dimension of CSR.

Following this knowledge, it is not appropriate for a company to aim only at a profit. It is necessary to be aware of the employees' and community welfare (people) also as environmental sustainability (planet) (Kurniatama et al., 2021). Mainly multinational and large companies are more active in implementing CSR activities (Haleem et al., 2021), and they focus on the implementation of all its dimensions.

On the other hand, most of the SME companies try to pick up only some dimensions or practices to implement. As is shown in Metzker et al. (2021) study, the implementation of the CSR concept also depends on the country's origin. It could be caused by the fact that less developed countries have to tackle issues as corruption, controlled media, less purchasing power, which can have a negative impact on the implementation of CSR (and as it was mentioned above, the price remain as one of the most important purchases decision tools). This knowledge is not proven by Haleem et al. (2021), which consider their results quite surprising because it did not confirm the positive impact of country characteristics on adopting sustainability practices. Stojanovic et al. (2020) look at the barriers of CSR implementation, which were considered as lack of knowledge about CSR concept, CSR culture, managerial failures, etc.

We believe reporting CSR build a better image, but without effective and credible implementation of CSR principles, it is something like greenwashing, which can lead to the disappointment of stakeholders and disbelief in CSR principles. One of the most known critics of the CSR concept is Milton Friedman, who claims that the only social responsibility of the company is to achieve profit (Nadanyiova, 2021). Another important critic of CSR is Reich, who claims if the company adopts the CSR concept, they indirectly undertake the government's obligation (Kurniatama et al., 2021).

\subsubsection{People (stakeholders) in the concept of CSR}

Responsibility of a company is not only towards the stakeholders, but also towards each group which could be influenced or influence the company. These stakeholder groups could be named as employees, consumers, suppliers, local communities, management of a company etc. (Kurniatama et al., 2021).

Can be no doubt that the employees are the most valuable capital of a company, as it is proven by many studies (Kurniatama et al., 2021; Golob and Podnar, 2021; Glavas, 2016), and skilled employees have become significant article to achieve (Gajanova, 2020). Following this knowledge, we can claim that employees are one of the most important stakeholders and are able to influence the success of the company, so it is a necessity to be focused on their satisfaction or well-being from the CSR point of view and create a safe workplace for them (Vagner, 2021). Many studies prove the positive effect of the CSR concept on employees because CSR can create an excellent social environment in the company (Golob and Podnar, 2021). CSR can positively affect the employee's engagement, and this effect is multiplied if they are allowed to show their authenticity. CSR influence job satisfaction, and thus it also affects life satisfaction (Glavas, 2016), and when we generalize this knowledge, we can claim that CSR influence global life satisfaction (Golob and Podnar, 2021). Vveinhardt and Sroka (2021) argue that CSR is a valuable tool for promoting the employment rate in a company through a lower rate of fluctuation. Authors consider CSR a tool of higher attractiveness of the company from the potential employees' point of view. Liu et al. (2020) stress that employees in CSR-oriented companies are more innovation-oriented, 
so the study considers CSR an important factor for innovations. Many studies created a positive picture of CSR as they consider CSR as a tool to a higher level of company's commitment, better identification with the company, trust (Brieger et al., 2020; Nazir and U1 Islam, 2020), employees are less willing to quit their job (Vveinhardt and Sroka, 2021), engagement, or job satisfaction with work for a socially responsible company (Golob and Podnar, 2021). A study by Stojanovic et al. (2020) pointed out the positive impact of the employees' loyalty to the company's performance and competitiveness. Only a few studies are focused on the black side of CSR implementation. This negative effect of the CSR is concerning with the high level of employees' engagement and considering their work more meaningful, which could have on the one hand good effect on their performance but on the other hand, it could lead to workaholism or job addiction which lead to degradation of their private life and well-being (Brieger et al., 2020). Bieger et al. (2021) see the possible negative impact of CSR on the employee in three dimensions - self-sacrifice (meeting other people's needs instead of own needs); stagnation (CSR as a tool of undermaintain of employee's development and self-expression); self-righteousness (when employees are strongly identified with the employer). In all these mentioned studies, it is crucial to stress that employees perceived CSR activities of the company.

In the era of globalization and accelerating competition, it is difficult for customers to find out the proper producer. As we know, the loyal customer is much more important and valuable compared to a new one. In this point of view, CSR is considered as the light element of competitiveness. Many studies prove that CSR positively impacts customer loyalty and customer identification with a company (Moisescu and Gica, 2020) because customers mainly relate product quality to CSR-oriented companies (Bardos et al., 2020). Also, productmarket perception is higher, mainly for standardized goods and highly competitive industries, the customer satisfaction is higher (Bardos et al., 2021). Metzker et al. (2021) also confirm the positive influence of the CSR concept on repurchase behaviors. Islam et al. (2021) consider the CSR concept the key strategy to build and maintain customer strategy. Another issue to tackle is CSR influence not only on the positive attitudes of customers but also in the point of view of failure. Alhouti et al. (2021) researched if CSR has a positive effect on the positive perception of the company if the service failure occurs. Their study confirms that CSR is a very useful tool for company failure, which can create positive attitudes to the company even if the customer is disappointed by the failure. The same results are proved by Kang et al. (2021), who additional claim that pre-crisis CSR could be the tool to overcome bad word-of-mouth and support the fact that customers are more resistant to believe in this type of negative information.

\subsubsection{Environment dimension in CSR concept}

Vagner (2021) emphasized the role of the companies in enhancing the environment by raising the consciousness of the stakeholders like customers, suppliers, or employees. Musova et al. (2021) studied why consumers are environmentally responsible. The results of the study reveal that the main force to behave more environmentally responsible is internal belief, ambition to be a model role for a community, or protection of non-renewable resources. But also, as the study of Boccia et al. (2019) stresses the fact that the price is still one of the most important factors for decision making even if the consumers are responsible oriented. But it also emphasizes that in the condition of the Slovak republic, people still disbelieve companies' efforts to protect the environment (Musova et al., 2021). Moisecu and Gica (2020) researched environmental orientation based on age and found that generation $Y$ is more environmentally orientated than generation $\mathrm{X}$ (generation $\mathrm{X}$ is more socially oriented). 


\subsubsection{Profit and CSR}

Implementation of the CSR concept is quite an expensive decision for the company. And if we take into account that CSR implementation is voluntary, the question "why the companies should implement CSR in their practices" arise. According to Stojanovic et al. (2020) and studies mentioned above (Bardos et al., 2020; Islam et al., 2021), CSR positively impacts the company's good reputation, which ensures the long-term differentiation of a company; subsequently, the customers' loyalty leads to better profit results. So, we can assume the positive relationship between CSR and profit. A lot of various studies conducted all over the world revealed a positive effect of CSR on the corporate value and the profit of the companies (Kurniatama et al., 2021; Boccia et al., 2019). Kurniatama et al. (2021) also stress the fact that CSR is a potential tool for the company to attract investors. Bardos et al. (2020) emphasize the mediating role of CSR between the improvement of the market position and the value of the company. From the strategic CSR point of view, it is also proved that CSR has a positive impact on the financial performance of the company (Sayekti, 2015). Valaskova et al. (2020) consider both - positive and negative effects of CSR implementation. Authors appreciate the positive impact of CSR as developing the strategic resources, insuring against risks, or supporting profit, but on the other hand, they stress the fact that implementation of CSR costs money.

Moreover, study by Rjiba et al. (2020) shows that CSR investments are paid out because if the company implemented CSR, it could reduce the risk concerning economic policy uncertainty. It can prevent its negative effect on the financial performance of the company. This knowledge is more evident in developed countries, which could be caused by the fact that the customers in the developed countries are more aware of the necessity to behave more socially and environmentally responsible. Apart from the previous studies, the study of Kurniatama et al. (2021) surprisingly shows that there is no evident effect of CSR on the corporate value or profitability of the company (which was measured as ROA).

\section{METHODS}

As the companies have to face increasing pressure to implement CSR practices in their operation, they also have to face the necessity to report these activities. Reporting is an essential part of the company's presentation to all types of stakeholders. But in recent years the financial reporting is not the only type of published information that is requested. Nonfinancial information has become a new trend for the companies to report, and if the company wants to inform all interested groups, CSR reporting is one of the ways how to make it. It could help the company to inform about its activities which are voluntary and beyond the condition required by law, with the aim to create a better picture of the company. If the company is transparent, it signalizes to investors that the company will capitalize their money (Nadanyiova and Gajanova, 2020). But as say Nazari et al. (2017), it could also be used as a type of green-washing, or another problem is that the reports are difficult to read.

But how many companies report their CSR activities? Are these activities domain only for developed countries, or are countries worldwide involved in these activities? The analysis of the GRI reports is the main method to answer these questions.

\section{RESULTS}

The Global Reporting Initiative (GRI) focuses on sustainability reporting and preparing the guidelines for reporting the companies' sustainability practices. As it is stated on the website of GRI, its mission is to "create a sustainable future." As mentioned above, many reports are hard to understand, so GRI tries to "create the global common language" that is 
easy to understand and helps the companies publish their impacts and actions in a sustainable future. The reports consist of three categories respecting three dimensions of CSR economical, environmental, and social. It is necessary to point out that GRI initiative is voluntary so that it could be assumed that the organizations participating in GRI initiative are trying to improve their CSR reporting (Crisostomo et al., 2017).

We searched the GRI reports through the years 2017 -2020. In 2017 there were published 1195 reports. In 20181694 reports were published, in 2019, it was 1285 reports, and in 2020 only 10 reports have been published so far. We assume that recordings' decreasing in 2019 was caused by the pandemic of COVID-19, because the reports are published next year as the reference period is. In 2020 the GRI made a revision of the system.

We analyzed the year 2018 when the highest rate of reports was published. This year, the organizations from 80 countries publish their reports following GRI. Figure 1. depicts dividing the number of reports according to the continent.

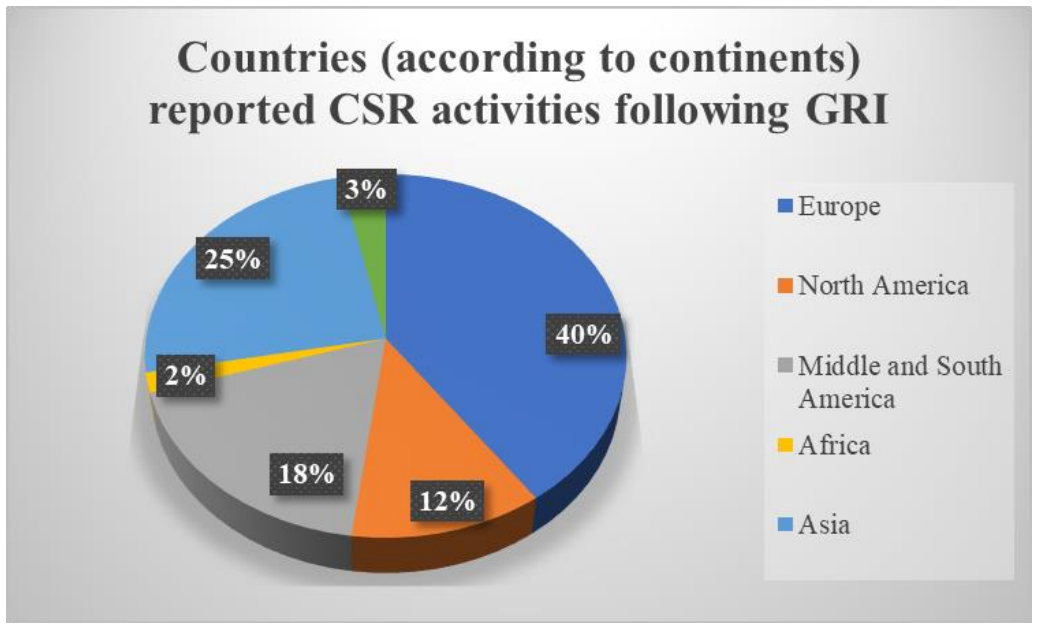

Figure 1 Countries reported CSR activities according to GRI

Source: authors (according to GRI reports)

The USA is the country with a higher level of reporting. From the European continent, Spain, Germany, and Sweden are the countries which report their CSR activities the most. Brasilia, Columbia, and Chile report the most in the Middle and South America. Only five countries report in Africa, namely Egypt, Ghana, Madagascar, Morocco, Nigeria, and South Africa, whereby their reporting is very weak compared to other countries of the world. In Asia, 26 countries report, and the country with the most reportings are Singapore, Thailand, and Taiwan.

When we focus on Visegrad 4 (V4) countries, in 2018, only Czech Republic, Poland and Hungary reported their CSR activities. Most organizations that reported these activities were from Poland (seven organizations) and then the Czech Republic and Hungary (both have four organizations). From Slovakia, only one company publish its CSR activities. It is Esset that started reporting in 2019. As it is assumed by Crisostomo et al. (2017), private companies have higher tendency to report than non-profit. All reporting organizations from V4 countries were private.

\section{DISCUSSION AND CONCLUSIONS}

Corporate social responsibility has become a valuable tool to attract stakeholders. It is a mark of a modern company which is not focused only on the profit, but it is also interested 
in the impact which can have on its environment. And as many studies reveal, mainly the young generation is responsible oriented and want the companies to be more transparent. But how to inform about CSR activities in a way which not be looking like greenwashing? How to announce a company's activities in an understanding way?

GRI tries to help companies worldwide with its guidelines on presenting the data about the responsible behavior of the company. As we mentioned above, many countries around the world are reporting their activities. Most of them are from developed countries, but also developing countries try to join this initiative. Following the result of our analysis, we can see that 1694 organizations from 80 countries try to come close to stakeholders and want to inform them about their activities. We can also claim that CSR reporting is not the only domain of developed countries. But there are limitations of our analysis that could be more searched in the future. The following study could focus on the statistical proof of any relationship between the development of the country and the willingness to publish the reports or the quality of published information.

\section{References}

1. Alhouti, S., Wright, S.A., \& Baker, T.L. (2021). Customers need to relate: The conditional warm glow effect of CSR on negative customer experiences. Journal of Business Research, 124, 240-253

2. Bardos, K. S., Ertugrul, M., \& Gao, L. S. (2020) Corporate social responsibility, product market perception, and firm value. Journal of Corporate Finance, 62, 101588.

3. Boccia, F., Manzo, R. M., \& Covino, D. (2019). Consumer behavior and corporate social responsibility: An evaluation by a choice experiment. Corporate Social Responsibility and Environmental Management, 26(1), 97-105

4. Brieger, S. A., Anderer, S., Froehlich, A., Baero, A., \& Meynhardt, T. (2020). Too Much of a Good Thing? On the Relationship Between CSR and Employee Work Addiction. Journal of Business Ethics, 166(2), 311-329.

5. Crisostomo, V. L., Prudencio, P. D., \& Forte, H. C., (2017). An analysis of the adherence to GRI for disclosing information on social action and sustainability concerns. Advances in Environmental Accounting and Management, 6, 69-103.

6. Gajanova, L., Nadanyiova, M., Musat, M., \& Bogdan, A. (2020). The social recruitment as a new opportunity in the Czech Republic and Slovakia. Ekonomicko-manazerske spektrum, 14(1), 65-76.

7. Glavas, A. (2016). Corporate Social Responsibility and Employee Engagement: Enabling Employees to Employ More of Their Whole Selves at Work. Frontiers in psychology, 7, 796.

8. Global Reporting Initiative (2020, December). Sustainability Disclosure Database. https://www.globalreporting.org/reportregistration/verifiedreports

9. Golob, U., \& Podnar, K., (2021). Corporate marketing and the role of internal CSR in employees' life satisfaction: Exploring the relationship between work and non-work domains. Journal of business research, 131, 664-672.

10. Friedman, M. (1970). The Social Responsibility of Business is to Increase its Profits. The New York Times Magazine, 122-126.

11. Haleem, F., Farooq, S., \&Boer, H., (2021). The impact of country of origin and operation on sustainability practices and performance. Journal of cleaner production, 304, 127097.

12. Islam, T., Islam, R., Pitafi, A. H., Liang, X. B., Rehmani, M., Irfan, M., \& Mubarak, M. S. (2021). The impact of corporate social responsibility on customer loyalty: The 
mediating role of corporate reputation, customer satisfaction, and trust. Sustainable Production and Consumption, 25, 123-135.

13. Kang, J. Y., Slaten, T., \& Choi, W. J. (2021). Felt betrayed or resisted? The impact of pre-crisis corporate social responsibility reputation on post-crisis consumer reactions and retaliatory behavioral intentions. Corporate Social Responsibility and Environmental Management, 28(1), 511-524.

14. Kurniatama, G. A., Robiyanto, R., Sasongko, G., \& Huruta, A. D. (2021). Determinants of Corporate Social Responsibility: Empirical Evidence from Sustainable and Responsible Investment Index. Quality-access to success, 22(183), 55-61

15. Liu, B. H., Sun, P. Y., \& Zeng, Y. L. (2020). Employee-related corporate social responsibilities and corporate innovation: Evidence from China. International Review of Economics \& Finance, 70, 357-372.

16. Metzker, Z., Belas, J. Jr., \& Amoah, J. (2021). The perception of using social media - a comparison of entrepreneurs implementing CSR in managerial practice and other entrepreneurs in selected V4 countries. Marketing and Management of innovations, 2, 191-203.

17. Moisescu, O. I., \& Gica, O. A. (2020). The Impact of Environmental and Social Responsibility on Customer Loyalty: A Multigroup Analysis among Generations X and Y. International Journal of Environmental Research and Public Health, 17(18), art. No. 6466

18. Musova, Z., Musa, H., \& Matiova, V. (2021). Environmentally responsible behaviour of consumers: Evidence from Slovakia. Economics and Sociology, 14(1), 178-198.

19. Nadanyiova, M. (2021). The perception of corporate social responsibility and its impact on consumer buying behaviour in the process of globalization. SHS Web of Conferences, 92, 06024

20. Nadanyiova, M., \& Gajanova, L. (2020). The impact of Corporate Social Responsibility on brand loyalty in the process of globalization. SHS Web of Conferences, 74, 04017.

21. Nazari, J. A., Hrazdil, K., \& Mahmoudian, F. (2017). Assessing social and environmental performance through narrative complexity in CSR reports. Journal of contemporary accounting \& economics, 13(2), 166-178.

22. Nazir, O., \& Ul Islam, J. (2020). Effect of CSR activities on meaningfulness, compassion, and employee engagement: A sense-making theoretical approach. International Journal of Hospitality Management, 90, 102630

23. Rjiba, H., Jahmane, A., \&Abid, I. (2020). Corporate social responsibility and firm value: Guiding through economic policy uncertainty. Finance Research Letters, 35, 101533.

24. Sayekti, Y. (2015). Strategic Corporate Social Responsibility (CSR), Company Financial Performance, and Earning Response Coefficient: Empirical Evidence On Indonesian Listed Companies. Procedia Social and Behavioral Sciences, 211, 411-420.

25. Shemyatikhina, L., Shipitsyna, K., \& Usheva, M. (2020). Marketing management of a non-profit organization. Ekonomicko-manazerske spektrum, 14(1), 19-29.

26. Stojanovic, A., Milosevic, I., Arsic, S., Urosevic, S., \& Mihajlovic, I. (2020). Corporate social responsibility as a determinant of employee loyalty and business performance. Journal of Competitiveness, 12(2), 149-166

27. Vagner, L. (2021). Public awareness of circular economy: Case of Slovak Republic. Ekonomicko-manazerske spektrum, 15(1), 97-110. 
28. Valaskova, K., Gavurova, B., Durana, P., \& Kovacova, M. (2020). Alter Ego Only Four Times? The Case Study of Business Profits in the Visegrad Group. E\&M Economics and Management, 23(3), 101-119.

29. Vveinhardt, J., \& Sroka, W. (2020). Mobbing and corporate social responsibility: does the status of the organisation guarantee employee wellbeing and intentions to stay in the job? Oeconomica Copernicana, 11(4), 743-778. 